\title{
Analisis Neutronik pada Gas Cooled Fast Reactor (GCFR) dengan Variasi Umur Teras dan Daya Reaktor
}

\author{
Widya Sardi ${ }^{*}$, Dian Fitriyani, Feriska Handayani Irka \\ Laboratorium Fisika Nuklir, Jurusan Fisika \\ Fakultas Matematika dan Ilmu Pengetahuan Alam Universitas Andalas \\ Kampus Unand Limau Manis, Padang, 25163, Indonesia \\ *widyasardi29@yahoo.co.id
}

\begin{abstract}
ABSTRAK
Telah dilakukan analisis neutronik pada Gas Cooled Fast Reactor (GCFR) dengan variasi umur teras dan daya reaktor. Reaktor ini menggunakan uranium alam sebagai bahan bakar dan helium sebagai pendingin. Parameter neutronik yang diamati meliputi faktor multiplikasi $\left(k_{\text {eff }}\right)$ dan densitas bahan bakar. Pengaturan bahan bakar menggunakan strategi shuffling pada model teras silinder dua dimensi R-Z.Teras dibagi menjadi 10 region. Setiap 10 tahun bahan bakar yang ada pada masing-masing region di shuffling ke region berikutnya. Bahan bakar di region 10 dikeluarkan sedangkan pada region 1 akan diisi dengan bahan bakar baru. Penelitian ini dilakukan dengan 3 variasi umur teras dan 3 variasi daya reaktor. Perhitungan menggunakan kode SRAC dengan JENDL-32 sebagai data library. Hasil perhitungan menunjukkan bahwa reaktor dapat dioperasikan hingga 100 tahun pada daya 500 MWTh karena neutron yang berada dalam teras reaktor dapat mempertahankan kekritisannya selama reaktor beroperasi. Semakin lama umur teras maka nilai densitas ${ }^{235} \mathrm{U}$ dan ${ }^{238} \mathrm{U}$ semakin berkurang dan nilai densitas ${ }^{239} \mathrm{Pu}$ semakin bertambah. Semakin tinggi daya yang digunakan maka densitas bahan bakar yang tersisa di akhir periode burn up lebih rendah.
\end{abstract}

Kata kunci : Burn up, faktor multiplikasi, GCFR, shuffling, uranium alam

\begin{abstract}
Neutronic analysis has been conducted for Gas Cooled Fast Reactor (GCFR) with variation of reactor core age and power. This reactor uses uranium as fuel and helium as a coolant. The observed neutronic parameters include multiplication factor $\left(k_{\text {eff }}\right)$ and fuel density. Fuel arrangement using shuffling strategy on two-dimensional cylinder $R-Z$ terrace model with the division of the terrace into 10 regions. Every 10 years of fuel in each region is shuffling to the next region. Fuel in region 10 is released in region 1 will be filled with new fuel. This study was conducted with 3 variations of terrace age and 3 variations of reactor power. The calculation is done using the SRAC code with JENDL-32 as the data library. The calculation results show that the Reactor can be operated for up to 100 years at 500 MWTh power because neutrons inside the reactor core can maintain their criticality during reactor operation. The longer the age of the terrace the density value of ${ }^{235} U$ and ${ }^{238} U$ decreases and the density value of ${ }^{239} \mathrm{Pu}$ increases. The higher the power used the lower the density of remaining fuel density at the end of the burn up period.

Keywords : Burn up, multiplication factors, GCFR, shuffling, natural uranium
\end{abstract}

\section{PENDAHULUAN}

Indonesia termasuk salah satu negara dengan tingkat pertambahan penduduk yang sangat tinggi yaitu sekitar 6\% per tahun, sehingga membutuhkan energi listrik yang sangat besar (Kementrian Energi dan Sumberdaya Alam, 2016). Sumber-sumber energi terbarukan seperti tenaga air, angin, surya, dan gelombang belum dapat memenuhi kebutuhan energi listrik di Indonesia (Aziz, 2008). Salah satu energi alternatif yang bisa digunakan untuk mengatasi masalah energi di Indonesia adalah energi nuklir (Pembangkit Listrik Tenaga Nuklir/ PLTN). Energi nuklir yang dihasilkan dari suatu reaktor nuklir merupakan sumber energi listrik yang relatif murah, aman, dan tidak mencemari lingkungan. Reaktor nuklir dalam perkembangannya memiliki 5 generasi, yaitu generasi I, generasi II, generasi III, generasi $\mathrm{III}^{+}$, dan generasi IV.

Reaktor generasi IV merupakan reaktor yang sedang dikembangkan oleh para ilmuwan saat ini. Keunggulan dari reaktor generasi IV adalah dalam hal efisiensi bahan bakar tinggi, limbah nuklir rendah, lebih ekonomis, mempunyai keandalan dalam beroperasi, keamanan yang tinggi, tidak rentan terhadap penyebaran bahan bakar nuklir berbahaya serta tidak membutuhkan daerah ekslusif di sekitar reaktor meskipun dalam kondisi kecelakaan (Driscoll dan Heizler, 2005). 
Salah satu jenis reaktor generasi IV adalah Gas-Cooled Fast Reactor (GCFR). GCFR merupakan reaktor yang memanfaatkan spektrum cepat dari neutron dan menggunakan jenis pendingin berupa gas, seperti helium (He), karbondioksida $\left(\mathrm{CO}_{2}\right)$, atau $\mathrm{N}_{2} \mathrm{O}_{4}$. GCFR mempunyai siklus bahan bakar tertutup, dimana bahan bakar yang telah digunakan dapat diolah kembali (GIF, 2009).

Penelitian yang berkaitan dengan analisis neutronik pada GCFR telah banyak dilakukan. Irka dan Su'ud (2015), melakukan analisis burn up pada reaktor cepat berpendingin gas menggunakan bahan bakar uranium alam dengan daya 700 MWTh. Hasil analisis menunjukkan bahwa reaktor yang dirancang mamiliki performa yang baik dengan nilai faktor multiplikasi neutron 1,055 .

Guskha (2016), melakukan analisis densitas nuklida lead-bismuth cooled fast reactor (LFR) berdasarkan variasi daya keluaran. Daya yang digunakan 300, 350, 400, 450, dan 500 MWTh. Hasilnya menunjukkan Inte.C.R dan densitas nuklida $\left({ }^{235} \mathrm{U},{ }^{238} \mathrm{U},{ }^{239} \mathrm{Pu}\right)$ yang paling optimal yaitu pada daya keluaran 300 MWTh.

Variasi pengaturan umur teras dan daya reaktor untuk GCFR belum ada yang melakukan. Maka pada penelitian ini akan dilakukan analisis neutronik pada gas cooled fast reactor (GCFR) dengan variasi umur teras dan daya reaktor. Variasi umur teras dapat mempengaruhi banyaknya refueling yang menyebabkan terjadinya perubahan densitas bahan bakar saat di burn up yang mempengaruhi kekritisan reaktor. Variasi daya dapat mempengaruhi banyaknya bahan bakar yang akan digunakan untuk proses strategi shuffling. Jika daya yang digunakan besar maka reaksi fisi yang terjadi juga besar sehingga membutuhkan bahan bakar yang banyak. Teras reaktor berada pada kondisi kritis apabila $\left(\mathrm{k}_{\mathrm{eff}}=1\right)$.

\section{METODE}

Penelitian ini menggunakan uranium alam sebagai bahan bakar dan helium sebagai pendingin. Strategi yang digunakan adalah strategi shuffling arah radial dengan tujuan agar bahan bakar yang digunakan tidak perlu lagi dilakukan pengkayaan. Teras reaktor dibagi menjadi 10 region yang memiliki volume yang sama secara radial seperti yang terlihat pada Gambar 1.

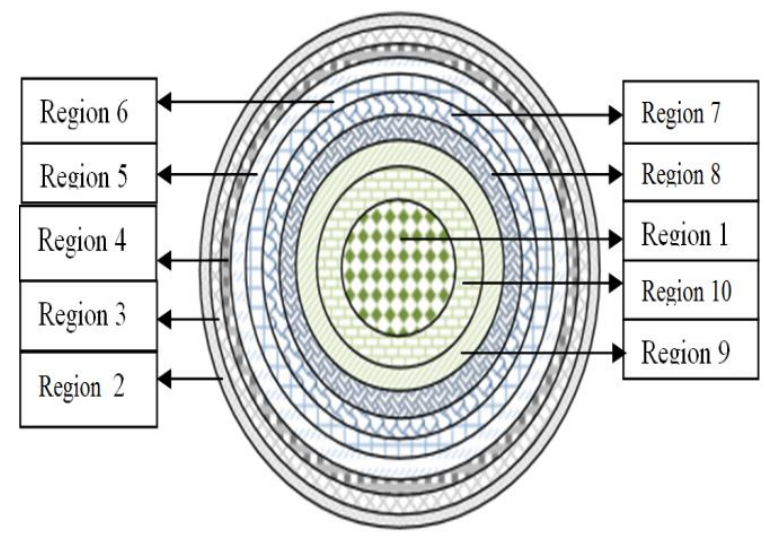

Gambar 1 Penampang lintang konfigurasi teras reaktor arah radial (sumber : Irka dan Su'ud, 2015) 


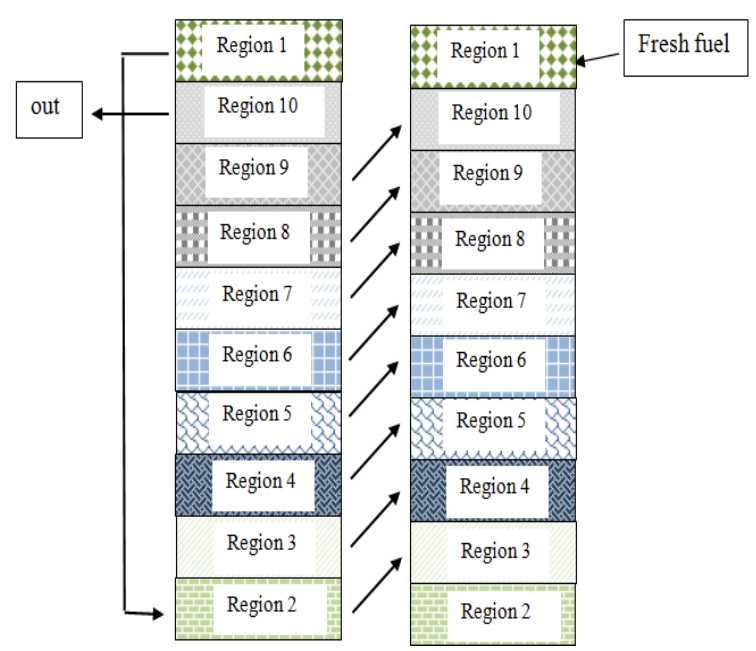

Gambar 2 Sistem shuffling arah radial (sumber : Irka dan Su'ud, 2015)

Awal operasi reaktor, masing-masing region diisi dengan bahan bakar uranium alam yang telah di-burn up terlebih dahulu. Setelah 10 tahun periode pembakaran, hasil burn up pada region 1 di-shuffling ke region 2, hasil burn up region 2 di-shuffling ke region 3, begitu seterusnya sampai hasil burn up region 9 di-shuffling ke region 10 dan hasil burn up region 10 dikeluarkan dari teras reaktor sehingga region 1 dapat diisi dengan bahan bakar baru (fresh fuel) yang terlihat seperti Gambar 2. Spesifikasi umum desain reaktor yang digunakan dapat dilihat pada Tabel 1.

Tabel 1 Spesifikasi umum desain reaktor

\begin{tabular}{ll}
\hline \multicolumn{1}{c}{ Parameter } & \multicolumn{1}{c}{ Deskripsi } \\
\hline Tipe teras & Cylinder cell \\
Geometri teras & 2-d cylinder \\
Jumlah region bervolume sama dalam arah radial & 10 region \\
Periode refueling & 10 tahun \\
Bahan bakar (fuel) & UN dan PuN \\
Struktur (cladding) & SS316 \\
Pendingin (coolant) & Helium \\
Fraksi bahan bakar & $65 \%$ \\
Fraksi struktur & $10 \%$ \\
Fraksi pendingin & $25 \%$ \\
Diameter pin/pitch & $1,4 \mathrm{~cm}$ \\
Lebar reflektor & $50 \mathrm{~cm}$ \\
\hline
\end{tabular}

Perhitungan neutronik pada penelitian ini dilakukan melalui kode komputasi Standard Reactor Analysis Code System (SRAC) yang dikembangkan oleh Japan Atomic Energy Research Institute (JAERI). Dengan menggunakan data nuklida dari JENDL-3.2. Diagram alir perhitungan dapat dilihat pada Gambar 3. 


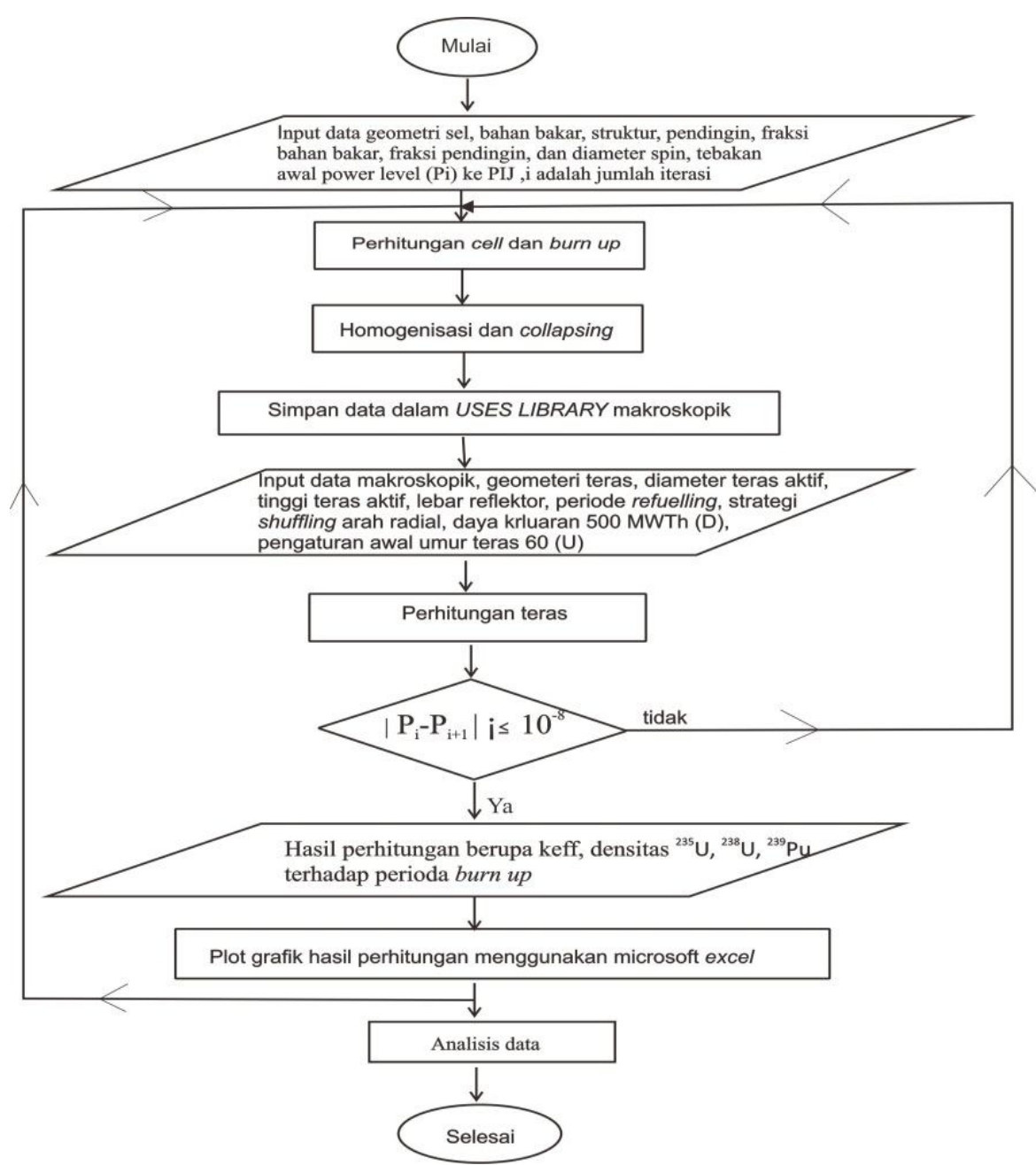

Gambar 3 Diagram alir perhitungan neutronik menggunakan SRAC

Analisis neutronik dilakukan untuk beberapa variasi umur teras dan daya reaktor yang dapat dilihat pada Tabel 2.

Tabel 2 Variasi umur teras dan daya reaktor

\begin{tabular}{ccc}
\hline Model & $\begin{array}{c}\text { Variasi } \\
\text { Umur } \\
\text { Teras } \\
\text { Reaktor } \\
\text { (Tahun) }\end{array}$ & $\begin{array}{c}\text { Variasi } \\
\text { Daya } \\
\text { (MWTh) }\end{array}$ \\
\hline 1 & 60 & 500 \\
& & 550 \\
2 & \multirow{2}{*}{80} & 600 \\
& & 500 \\
3 & \multirow{2}{*}{100} & 550 \\
& & 600 \\
& & 500 \\
& & 550 \\
\end{tabular}

\section{HASIL DAN DISKUSI}

\subsection{Nilai Faktor Multiplikasi $\left(\boldsymbol{k}_{\text {eff }}\right)$}

Nilai $k_{\text {eff }}$ pada penilitian ini ditinjau berdasarkan masa refueling, yaitu 10 tahun sekali. Nilai $k_{\text {eff }}$ ditinjau 2 tahun sekali selama satu kali periode refueling. Hubungan $k_{\text {eff }}$ terhadap periode burn up dapat dilihat pada Gambar 4. 

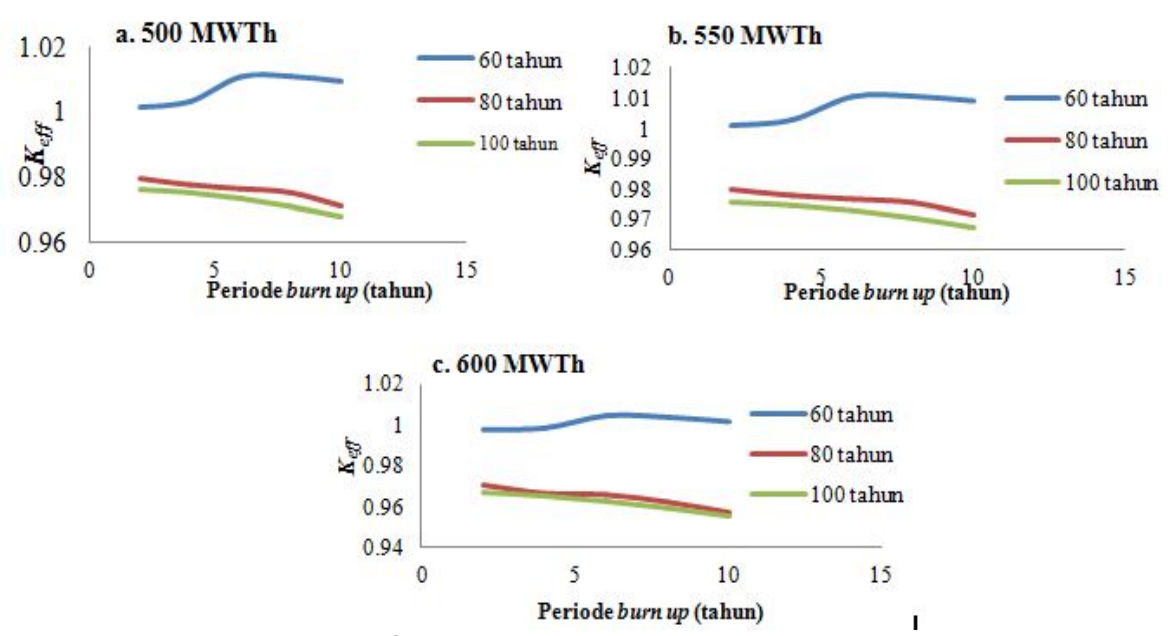

Gambar 4 Nilai $\mathrm{k}_{\text {eff }}$ terhadap periode burn up

Dua tahun periode burn up, nilai $k_{\text {eff }}$ untuk masing-masing daya hampir sama yaitu 1,004042, 1,001307, 0,9975031. Empat tahun berikutnya nilai $k_{\text {eff }}$ untuk umur 60 tahun meningkat, sedangkan untuk umur 80 tahun dan 100 tahun nilai $k_{\text {eff }}$ selalu cenderung turun seiring dengan lamanya periode burn up. Hal ini disebabkan karena semakin bertambahnya periode burn up, maka nilai densitas ${ }^{235} \mathrm{U},{ }^{238} \mathrm{U}$ yang ada dalam teras reaktor juga berkurang karena dipakai terus untuk pengoperasian reaktor, sedangkan densitas ${ }^{239} \mathrm{Pu}$ bertambah. Akhir periode burn up, densitas ${ }^{239} \mathrm{Pu}$ juga berkurang karena dipakai terus untuk pengoperasian reaktor. Berkurangnya densitas ${ }^{235} \mathrm{U},{ }^{238} \mathrm{U}$, dan ${ }^{239} \mathrm{Pu}$ menyebabkan neutron yang dihasilkan juga berkurang.

Daya 500 MWTh memiliki nilai $k_{\text {eff }}$ yang lebih besar dibandingkan dengan daya 550 MWTh dan 600 MWTh untuk masing-masing umur. Hal ini disebabkan karena daya yang kecil membutuhkan sedikit neutron untuk terjadinya reaksi fisi, sehingga pada akhir periode burn up jumlah neutron yang dihasilkan lebih banyak yang menyebabkan nilai $k_{\text {eff }}$ juga besar. Daya yang besar membutuhkan banyak neutron untuk terjadinya reaksi fisi, sehingga jumlah neutron yang dihasilkan sedikit yang menyebabkan nilai $k_{\text {eff }}$ dihasilkan juga kecil. Semua daya yang dirancang pada Tabel 3 memperlihatkan bahwa daya 500 MWTh yang lebih efektif, karena neutron dalam teras reaktor cenderung dipertahankan (jumlah populasi neutron dari satu generasi sama dengan generasi sebelumnya). Semua nilai $k_{\text {eff }}$ yang didapatkan masih berada dalam rentang ayunan reaktivitas $( \pm 0,05)$.

Modifikasi burn up dengan stratetegi shuffling arah radial memungkinkan reaktor beroperasi menggunakan uranium alam tanpa pengkayaan. Hal ini terbukti dari nilai faktor multiplikasi $\left(k_{\text {eff }}\right)$ yang didapatkan bahwa pada umur 100 tahun neutron yang berada dalam teras reaktor cenderung dipertahankan. Ini menandakan reaktor berada pada kondisi kritis dan dapat dioperasikan.

\subsection{Nilai Densitas $\left({ }^{235} \mathrm{U},{ }^{238} \mathrm{U}\right.$, dan $\left.{ }^{239} \mathrm{Pu}\right)$}

Hubungan nilai densitas terhadap periode burn up dapat dilihat pada Gambar 5, Gambar 6, dan Gambar 7. Gambar 5 memperlihatkan hubungan densitas ${ }^{235} \mathrm{U}$ terhadap periode burn up. 

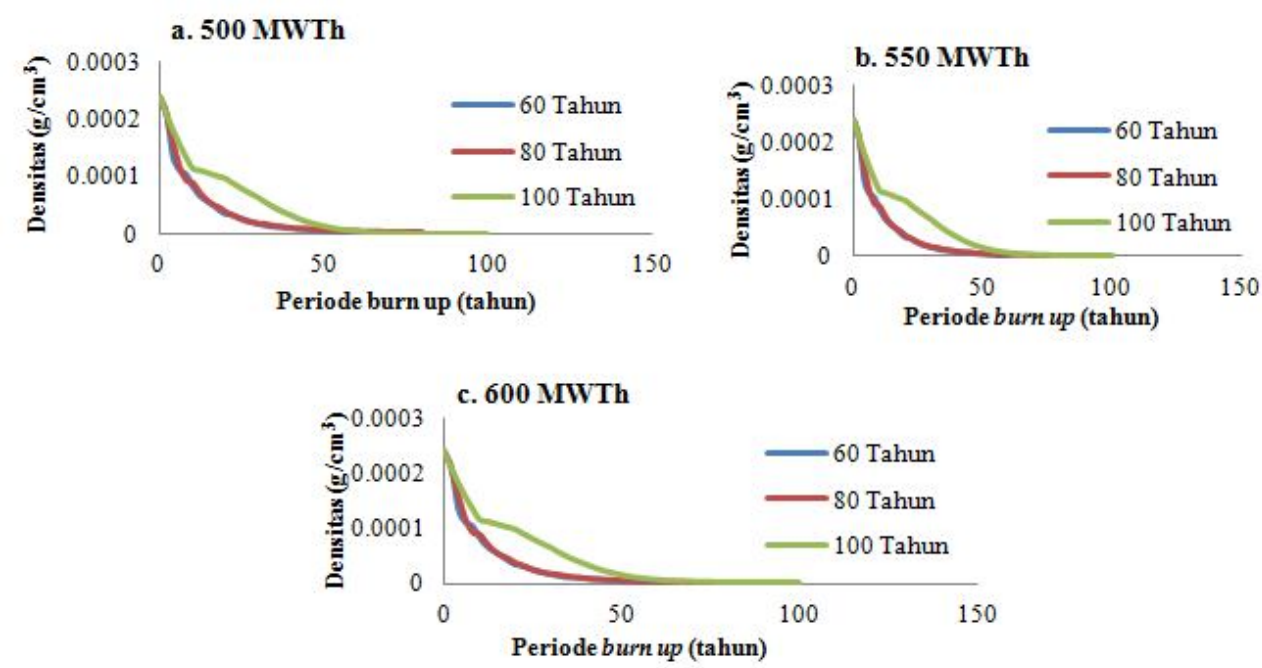

Gambar 5 Nilai densitas ${ }^{235} \mathrm{U}$ terhadap periode burn up

Awal periode burn up, densitas ${ }^{235} \mathrm{U}$ untuk masing-masing umur teras reaktor memiliki nilai yang sama yaitu $2,39 \times 10^{-4} \mathrm{~g} / \mathrm{cm}^{3}$. Semakin lama dilakukan burn up maka nilai densitas ${ }^{235} \mathrm{U}$ juga semakin berkurang, yang menyebabkan jumlah neutron di teras reaktor juga berkurang. Hal ini disebabkan karena densitas ${ }^{235} U$ yang ada dalam teras reaktor terus dipakai untuk proses reaksi fisi agar reaktor dapat terus beroperasi. Akhir periode burn up, umur teras 60 tahun memiliki nilai densitas ${ }^{235} \mathrm{U}$ yang lebih besar dibandingkan dengan umur teras yang lain. Hal ini disebabkan karena reaktor dengan umur teras 60 tahun lebih dulu berhenti beroperasi dibandingkan dengan reaktor umur yang lain.

Semakin lama dilakukan burn up dengan daya yang besar maka nilai densitas ${ }^{235} \mathrm{U}$ untuk masing-masing umur juga semakin berkurang yang menyebabkan jumlah neutron di teras reaktor juga berkurang. Hal ini disebabkan karena daya yang besar membutuhkan neutron yang banyak agar terjadi proses reaksi fisi dalam teras reaktor yang menyebabkan reaktor dapat beroperasi. Akhir periode burn up, daya 500 MWTh memiliki neutron yang lebih banyak dibandingkan dengan yang lain. Hal ini disebabkan karena reaktor dengan daya $500 \mathrm{MWTh}$ lebih sedikit memerlukan neutron untuk pengoperasian reaktor dibandingkan dengan daya yang lain, sehingga daya 500 MWTh memiliki peluang yang besar untuk pengoperasian reaktor dalam jangka waktu yang lama.

Gambar 6 memperlihatkan hubungan densitas ${ }^{238} \mathrm{U}$ terhadap periode burn up. Awal periode burn up, densitas ${ }^{238} \mathrm{U}$ untuk masing-masing umur teras reaktor memiliki nilai yang sama yaitu $3,34 \times 10^{-4} \mathrm{~g} / \mathrm{cm} 3$. Semakin lama dilakukan burn up, nilai densitas ${ }^{238} \mathrm{U}$ untuk masingmasing umur teras semakin berkurang, yang menyebabkan jumlah neutron didalam teras reaktor juga berkurang. Hal ini disebabkan karena dilakukan burn up untuk merubah bahan yang bersifat fertil $\left({ }^{238} \mathrm{U}\right)$ menjadi bahan yang bersifat fisil $\left({ }^{239} \mathrm{Pu}\right)$ agar dapat berfisi dalam teras reaktor. Umur 60 tahun memiliki nilai densitas yang lebih banyak dibandingkan umur yang lain pada akhir periode burn up. Hal ini disebabkan karena proses reaksi fisi dalam teras reaktor berlangsung dalam jangka waktu yang lebih pendek dibandingkan umur yang lain.

Semakin lama dilakukan burn up dengan daya yang besar untuk mengubah bahan fertil $\left({ }^{238} \mathrm{U}\right)$ menjadi bahan fisil $\left({ }^{235} \mathrm{U}\right)$ maka nilai densitas ${ }^{238} \mathrm{U}$ untuk masing-masing umur juga semakin berkurang, yang menyebabkan jumlah neutron di teras reaktor juga berkurang. Hal ini disebabkan karena daya yang besar membutuhkan neutron yang banyak dalam teras reaktor untuk mengubah bahan fertil menjadi bahan fisil. Akhir periode burn up, daya 500 MWTh memiliki neutron yang lebih banyak dibandingkan dengan daya yang lain. Hal ini disebabkan karena reaktor dengan daya 500 MWTh lebih sedikit memerlukan neutron untuk mengubah bahan fertil menjadi bahan fisil dibandingkan dengan daya yang lain, sehingga daya $500 \mathrm{MWTh}$ memiliki peluang yang besar untuk pengoperasian reaktor dalam jangka waktu yang lama. 

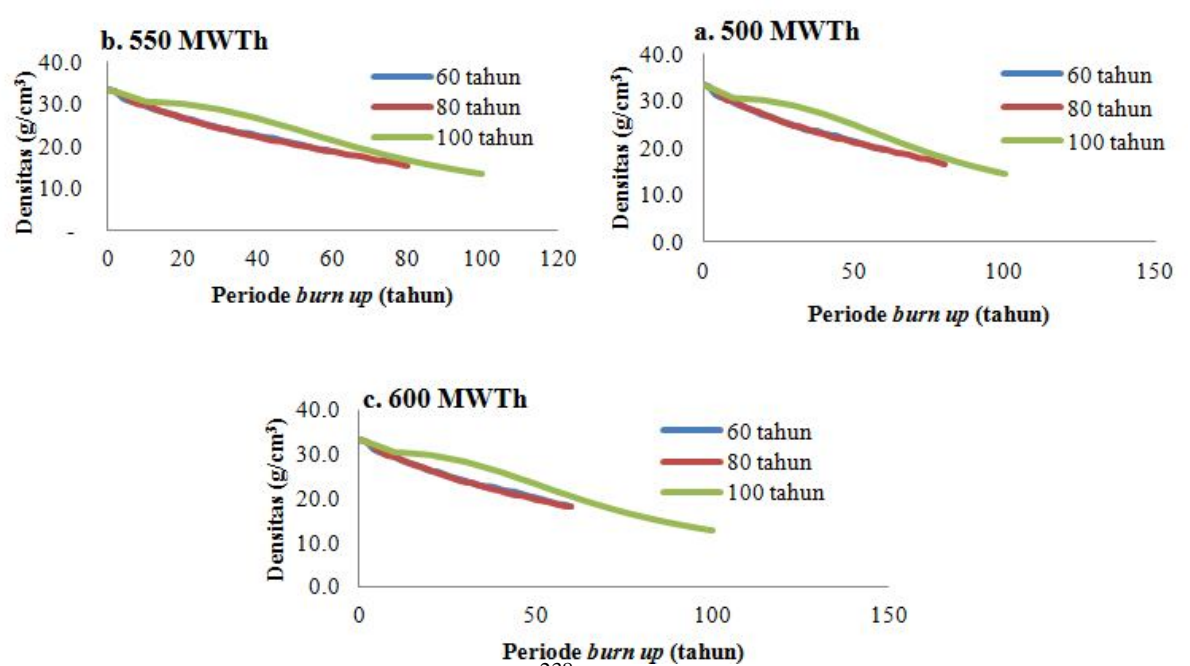

Gambar 6 Nilai densitas ${ }^{238} \mathrm{U}$ terhadap periode burn up
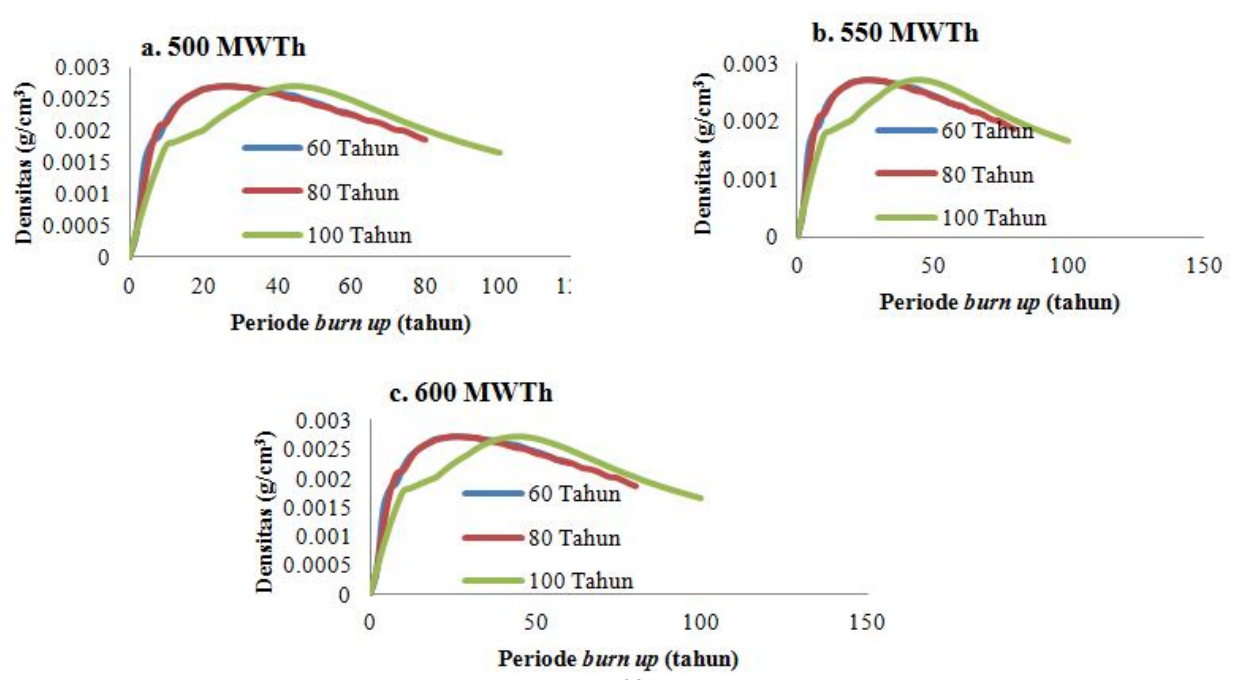

Gambar 7 Nilai densitas ${ }^{239} \mathrm{Pu}$ terhadap periode burn up

Gambar 7 memperlihatkan hubungan densitas ${ }^{239} \mathrm{U}$ terhadap periode burn up. Awal periode burn up, densitas ${ }^{239} \mathrm{Pu}$ untuk masing-masing umur tidak ada didalam teras reaktor. Semakin lama dilakukan burn up, nilai densitas ${ }^{239} \mathrm{Pu}$ untuk masing-masing umur teras semakin bertambah, yang menyebabkan jumlah neutron didalam teras reaktor juga bertambah. Hal ini disebabkan karena densitas ${ }^{239} \mathrm{Pu}$ dihasilkan dari reaksi neutron cepat dengan ${ }^{238} \mathrm{U}$ yang bersifat fertil. Setelah mencapai puncak maksimum nilai densitas ${ }^{239} \mathrm{Pu}$ untuk masing-masing umur teras reaktor kembali turun. Hal ini disebabkan karena densitas ${ }^{239} \mathrm{Pu}$ dipakai terus untuk proses fisi agar reaktor dapat terus beroperasi. Daya 600 MWTh untuk masing-masing umur lebih cepat mencapai puncak maksimum dibandingkan dengan daya yang lain karena membutuhkan reaksi fisi yang relatif besar dalam pengoperasian reaktor, dan cepat pula menurun karena membutuhkan neutron yang banyak untuk proses reaksi fisi. Akhir periode burn up umur teras 60 tahun memiliki nilai densitas ${ }^{239} \mathrm{Pu}$ yang lebih banyak dibandingkan dengan umur yang lain. Ini disebabkan karena waktu yang diperlukan reaktor umur 60 tahun untuk beroperasi lebih singkat dibandingkan dengan reaktor umur yang lain.

Setelah 10 tahun periode burn up nilai densitas ${ }^{239} \mathrm{Pu}$ untuk masing-masing daya meningkat. Hal ini disebabkan karena densitas ${ }^{239} \mathrm{Pu}$ merupakan hasil dari reaksi neutron cepat dengan ${ }^{238} \mathrm{U}$ yang bersifat fertil. Setelah 40 tahun periode burn up nilai densitas ${ }^{239} \mathrm{Pu}$ masingmasing daya kembali menurun karena dipakai terus untuk proses reaksi fisi untuk pengoperasian reaktor. Sehingga di akhir periode burn up daya 500 MWTh yang memiliki densitas paling besar, karena hanya membutuhkan sedikit reaksi fisi untuk pengoperasian reaktor yang menyebabkan neutron banyak tersisa. 


\section{KESIMPULAN}

Berdasarkan hasil penelitian dapat diketahui bahwa reaktor GCFR yang dirancang pada penelitian ini dapat dioperasikan hingga 100 tahun pada daya 500 MWTh dengan kinerja neutronik yang baik. Hal ini ditunjukkan dengan neutron yang berada dalam teras reaktor dapat mempertahankan kekritisannya selama reaktor beroperasi. Semakin lama umur teras maka nilai densitas ${ }^{235} \mathrm{U}$ dan ${ }^{238} \mathrm{U}$ semakin berkurang dan nilai densitas ${ }^{239} \mathrm{Pu}$ semakin bertambah. Akhir periode burn up nuklida ${ }^{239} \mathrm{Pu}$ mengalami penurunan kembali dikarenakan telah mengalami reaksi fisi dengan neutron. Semakin tinggi daya yang digunakan maka densitas bahan bakar yang tersisa di akhir periode burn up lebih sedikit.

\section{DAFTAR PUSTAKA}

Aziz, F., Solusi Bijak Krisis Listrik, Majalah Gatra, ed. 12 November 2008.

Driscroll, M. J. dan P. Heizler., "Reactor Physic Challenges in Gen IV Reactor Desaign", Jurnal Nuclear Engineering and Technology, 27, 1-10, (2005).

Irka, F. H., "Studi Desain Reaktor Cepat Berpendingin Gas dengan Bahan bakar Uranium Alam menggunakan Strategi Shuffling Arah Radial", Tesis S2, ITB, 2011.

Irka, F.H dan Su'ud, Z., "Analisis Burn-Up pada Reaktor Cepat Berpendingin Gas menggunakan Bahan Bakar Uranium Alam" Jurnal Ilmu Fisika, 7, 78-86, (2015).

Guskha, C.R, Shafii, M. A, dan Irka, F.H, "Analisis Densitas Lead-Bismuth Cooled Fast Reactor (LFR) berdasarkan Variasi Daya Keluaran”, Jurnal Fisika Unand, 5, 7-13, (2016).

GIF., GIF R\&D Outlook For Generation IV Nuclear Energy System, 2009, diakses pada 15 Juli 2017.

Kementerian ESDM., 2016, Hingga 2030 permintaan energi dunia meningkat 45\%, :http://www.esdm.go.id/berita/37-umum/2133, diakses pada 15 Juli 2017. 